\title{
ANALYSIS ON THE PERCEPTION OF THE MANAGERS OF LODGING BUSINESSES TOWARD ONLINE SHORT-TERM RENTAL PLATFORMS
}

\author{
K. M. Ferreira ${ }^{1 *}$; M. P. Méxas ${ }^{2}$
}

1 Mestrado em Sistema de Gestão. Escola de Engenharia. Universidade Federal Fluminense (UFF)

2 Departamento de Engenharia Civil. Universidade Federal Fluminense (UFF)

*karolinamatias@gmail.com

Artigo submetido em 20/09/2017 e aceito em 09/12/2017

\begin{abstract}
When connecting travelers and property owners directly, the online short-term rental platforms have become stronger over the past years and, as they represent a type of innovation in the tourism sector, they may affect traditional lodging businesses directly. The present article aimed at investigating, according to the perception of the managers of lodging businesses in five cities of the State of Rio de Janeiro, how this type of collaborative consumption affects the competitiveness in their businesses. The qualitative research, of exploratory
\end{abstract}

nature, was performed by applying an electronic questionnaire. The results indicated two possible situations: the managers have limited knowledge of such themes and/or only part of what is reported in the literature was realized by them in their businesses. Taking into consideration how actual the approached theme is, the academic relevance of the present article stands out and it is expected that this article may contribute to a better understanding of the effects of such phenomena on the tourism sector.

KEYWORDS: Lodging businesses, online platforms, tourism, competitiveness, sharing economy, collaborative consumption

\section{ANÁLISE DA PERCEPÇÃO DE GESTORES DE MEIOS DE HOSPEDAGEM QUANTO ÀS PLATAFORMAS ONLINE DE ALUGUEL POR TEMPORADA}

\section{RESUMO}

Ao conectarem diretamente viajantes e proprietários de imóveis, as plataformas online de aluguel por temporada vêm ganhando força, nos últimos anos, e, por representarem um tipo de inovação no setor de turismo, podem afetar diretamente os meios de hospedagem tradicionais. $\mathrm{O}$ presente artigo teve por objetivo investigar, de acordo com a percepção de gestores de meios de hospedagem de cinco municípios do Estado do Rio de Janeiro, como esse tipo de consumo colaborativo afeta a competitividade de seus empreendimentos. A pesquisa qualitativa, de caráter exploratório, foi realizada por meio de aplicação de questionário eletrônico. Os resultados indicaram duas situações possíveis: os gestores possuem entendimento limitado sobre esses temas e/ou apenas parte do que é reportado na literatura foi percebido por eles em seus empreendimentos. Dada a atualidade do tema abordado, destaca-se a relevância acadêmica do presente artigo e espera-se que este contribua para um maior entendimento sobre os efeitos desses fenômenos no setor de turismo.

PALAVRAS-CHAVE: meios de hospedagem, plataformas online, turismo, competitividade, economia compartilhada, consumo colaborativo 


\section{INTRODUCTION}

A new tendency, named sharing economy, has recently appeared as an alternative to satisfy diverse needs, which were previously, fulfilled predominantly by businesses. The consumers decided to have access to products and pay for the experience of owning them temporarily, instead of purchasing them (BARDHI; ECKHARDT, 2012). The sharing of idle individual goods has become popular over the past years (CHOI et al., 2014). With the emerging of peer-to-peer technological platforms, new marketplaces based on collaborative consumption appeared and their impacts have already promoted significant changes in consumption patterns.

This characteristic of prioritizing the sharing of goods to the detriment of property is an interesting aspect of this tendency, because it goes against the essence of accumulation of goods, a characteristic of capitalism (CEROY, 2015). It is believed that, in the long run, the effects of sharing economy may be catastrophic for traditional industries and they will demand that the businesses, in order to keep competitive, offer more consistent, reliable and safer services to consumers (BOESLER, 2013; CUSUMANO, 2015).

In the tourism sector, collaborative consumption expresses itself in the business models of online short-term rental platforms, which have been getting stronger in this context of the advent of social media and sharing economy. Basically, prospective hosts list their properties, define the daily rates and announce them to the guests on such digital platforms (ZERVAS et al., 2015).

It is worth emphasizing that, when connecting travelers and property owners directly, such platforms consist of a type of innovation that may provoke changes to the consumption pattern of tourists and, thus, may affect traditional lodging businesses, once it represents a new entrant in the market.

It is important to remember that such innovations, which introduce a new product or business model into a certain industry, may significantly change the logistic of competition and may present competitive advantage in relation to the already established businesses, forcing them to adopt differentiated strategies to continue competing in the market (CHRISTENSEN, 2001).

Having in mind the information exposed above, it is considered essential to understand the impacts of such tendency. This study was specifically aimed at investigating how the collaborative consumption of accommodation, expressed by the online short-term rental platforms, is realized by the managers of lodging businesses from five cities of the State of Rio de Janeiro (Angra dos Reis, Armação dos Búzios, Cabo Frio, Paraty and Rio de Janeiro).

\section{LITERATURE REVIEW}

Cited for the first time in 2008 by Professor Lawrence Lessig at Havard University, the term "sharing economy" refers to the collaborative consumption made in the activities of sharing, exchange or rental of goods without their acquisition, necessarily. Such tendency has become popular in the past years, due to the sharing of idle individual goods. It is worth remembering that the tangible goods as well as the intangible ones started being shared in consumer-to-consumer (C2C) and business-to-consumer (B2C) negotiations (CHOI et al., 2014).

An interesting point about this new economic model that is worthy highlighting is the prioritization of sharing of goods to the detriment of property. This characteristic goes against the essence of capitalism, which consists of the accumulation of goods (CEROY, 2015).

Cusumano (2015) highlights that the startups which appear in sharing economy - online platforms that assemble individuals who have underused assets and people interested in renting them for short periods - constitute a new group of competitors for traditional businesses. He also 
mentions that such P2P networks may grow exponentially, becoming a threat to the established businesses. For the author, traditional businesses will need to offer more consistent, reliable and safer services than the ones offered by their competitors in sharing economy. Boesler (2013), in turn, highlights that in the future, the effects of such tendency may be catastrophic for traditional businesses, once this new consumption pattern (in which the consumer does not necessarily buy something, but rents it) would demand changes in sales, production and even employment structure.

Some examples of businesses that have thrived because of this tendency are Uber, Airbnb, Spotify, Neflix e Bliive. The forecast, according to some economists, is that this tendency will be responsible for moving a value equivalent to $\mathrm{R} \$ 1$ trillion in the next years (COMPARTILHAR..., 2015).

\section{MATERIALS AND METHODS}

The present study was constituted by four stages. The first stage considered the literature review on the central concepts of the article and are presented in Table 1. The second stage comprehended the definition of the universe and sample, which was formed by managers of lodging businesses from five cities of the State of Rio de Janeiro (Angra dos Reis, Armação dos Búzios, Cabo Frio, Paraty and Rio de Janeiro), which belong to category A on the Tourist Map of Brazil. In this category, there are the main cities in which the highest number of job opportunities, businesses in the lodging segment and tourist flow (MINISTRY OF TOURISM, 2016.) is registered. In the third stage, a field survey was performed to collect data along with the sample. And, in the end, the fourth stage consisted of the analysis and treatment of the collected data, which were treated through descriptive statistics, through the analysis of frequencies, the same way the mode was used, which represents the value that appears more often during the interpretation of graphics.

The data collection instrument consisted of a questionnaire with open and closed questions (the latter ones being the majority) and was structured in two sections. In the first section, it was aimed to obtain information on the respondents and the business they represent. In the second section, questions to identify the perception of the respondents toward online short-term rental platforms, collaborative consumption and sharing economy were delineated. In order to do so, a scale or classification question, more specifically the five-point Likert scale, was used, which allowed the respondents to indicate the degree to which they agree or disagree with some specific statement (GRAY, 2012). Besides, Table 1 below was created from a bibliometric study on sharing economy and collaborative consumption to support the statements in the questionnaire.

Table 1 - Rationale of the statements presented in the questionnaire.

\begin{tabular}{|l|l|}
\hline Author(s) & Statements \\
\hline Teubner (2014) & Governors must support the progress of this type of platforms. \\
\hline Quinson (2015) & $\begin{array}{l}\text { Platforms may contribute to mitigating the effects of the economic crisis } \\
\text { and global warming. }\end{array}$ \\
\hline Matzler, Veider and Kathan (2015) & $\begin{array}{l}\text { Businesses must adapt to the changes in the market and think of new ways } \\
\text { to generate income. }\end{array}$ \\
\hline Goel (2014) & $\begin{array}{l}\text { Consumers can refuse the products and services from traditional businesses } \\
\text { now. }\end{array}$ \\
\hline Hamari, Sjöklint and Ukkonen (2015) & $\begin{array}{l}\text { The economic benefits are the main motivational factor to participate in } \\
\text { activities to share goods and services. }\end{array}$ \\
\hline $\begin{array}{l}\text { Belk (2014) } \\
\text { Boesler (2013) } \\
\text { Cusumano (2015) } \\
\text { Matzler, Veider and Kathan (2015) }\end{array}$ & Platforms represent a threat to the already established companies. \\
\hline Bardhi and Eckhardt (2012) & Consumers prefer to pay to have access to products and goods temporarily \\
\hline
\end{tabular}




\begin{tabular}{|l|l|}
\hline $\begin{array}{l}\text { Botsman (2015) } \\
\text { Ceroy (2015) }\end{array}$ & (without the need to buy them). \\
\hline Henten and Windekilde (2016) & There is competition between the platforms and traditional businesses. \\
\hline Eckhardt and Bardhi (2015) & $\begin{array}{l}\text { Platforms benefit the consumers who look for more convenience and better } \\
\text { price. }\end{array}$ \\
\hline
\end{tabular}

Source: Own elaboration (2016)

\subsection{Analysis and data presentation}

Data collection consisted in submitting the research questionnaire via the SurveyMonkey platform to a total of 506 email addresses related to the businesses of the lodging segment from the cities of Angra dos Reis, Armação dos Búzios, Cabo Frio, Paraty and Rio de Janeiro. Those emails were disclosed by the Ministry of Tourism upon request, on November 13, 2015.

The invitations to answer the questionnaires were submitted to the email addresses on February 29, 2016. After submitting those, two more reminders were submitted, on March 8 and 15, only to the email addresses whose answers had not been obtained. Besides the invitations via email, 11 entities (associations, secretaries, unions) related to the lodging segment in the cities previously cited were hired, informing about the research and requesting assistance to disclose the questionnaire's link.

The contacts via email resulted in resulted in 46 answers to the questionnaire while 28 answers were obtained from the link submitted to the entities. From a total of 74 answers, 41 corresponded to complete answers, from which 37 were answers from people with management positions in the lodging enterprises. Bearing in mind the focus of the present work, only those 37 answers were considered for the analysis. The research questionnaire was available to be answered between February 29 and March 24, 2016.

It is worth mentioning, once the present study intended to evaluate only the perception of the managers of the lodging businesses, from a total of 41 complete answers received, only those that referred to managers of lodging businesses $(n=37)$ were considered for this analysis.

\section{RESULTS AND DISCUSSIONS}

\subsection{Characterization of the respondents and businesses}

It was verified that the majority of the respondents represent lodging businesses from the cities of Rio de Janeiro and Paraty, accounting for, respectively, 40,5\% and 37,8\% of the total. The cities of Armação dos Búzios and Angra dos Reis represented 8,1\% each and the city of Cabo Frio obtained the lowest representation, 5,4\%.

As for the classification of the lodging businesses. It is possible to realize that $37,8 \%$ are inns, $29,7 \%$ are hostels and $21,6 \%$ are hotels. From the total of businesses, 5,4\% are bed and breakfasts, while apart hotels and others represent $2,7 \%$, each. The classification farm hotel, historic hotel and resort were not observed.

The age of the lodging businesses was addressed in the third question in the questionnaire, making it possible to identify that the majority of the businesses had started operating between 4 and 6 years before the time this questionnaire was applied $(27,0 \%) ; 24,6 \%$ had been operating for more than 20 years; 21,6\% between 1 and 3 years; 13,5\%, between 10 and 15 years; and 13,5\%, between 15 and 20 years. Businesses operating for less than 1 year or between 7 and 9 years were not observed. It is worth highlighting that more than half of the businesses represented $(51,3 \%)$ started operating more than 10 years ago. 
The size of the business constitutes another important point for the research and thus, was considered in the fourth question. From the obtained answers, it was possible to considerate that $48,6 \%$ of the respondents were managers of micro businesses and 35,1\% managers of small-size businesses. The individual micro-entrepreneurs accounted for $13,5 \%$, while the medium-size businesses corresponded to only $2,7 \%$ of the total of answers. None of the answers referred to big companies. It is important to highlight that in this setting, in which the individual microentrepreneurs are predominant, the micro businesses and small-size businesses reflect an essential characteristic of the tourism sector, which is, in its majority, composed by small-size enterprises.

Questions 5 and 6 in the questionnaire aimed at knowing the number of housing units (HU) and beds in the lodging businesses. It was observed that $37,8 \%$ of the businesses have between 11 and $30 \mathrm{HUs}, 35,1 \%$ have up to $10 \mathrm{HUs}$ and $24,4 \%$ from 31 to $50 \mathrm{HUs}$. Only 2,7\% have more than 101 HUs.

About the number of beds, the predominance of lodging businesses with the number of beds between 31 and 50 beds and 51 and 100 beds (32,4\% each) was verified. Enterprises with up to 10 beds represented 5,4\%; more than 101 beds, $8,1 \%$; and 11 to 30 beds, $21,6 \%$. It is interesting to notice that the verified amount of HUs and beds is coherent with the size of the businesses identified previously. As most of the respondents represent small-size lodging businesses, it is natural that in its majority the enterprises have up to $50 \mathrm{HUs}$ and the amount of beds, consequently, up to 100 .

\subsection{Perception of collaborative consumption, sharing economy and online short-term rental platforms}

The questions of section 2 in the questionnaire aimed at evaluating the perception of the managers of lodging businesses toward collaborative consumption, sharing economy and online short-term rental platforms. When asked if they knew any short-term rental platforms, 25 managers $(67,5 \%)$ answered yes and $12(32,4 \%)$ answered no.

The managers who answered the previous question affirmatively indicated at least one platform they were acquainted with. It was observed that one manager mentioned four platforms, ten managers mentioned three platforms, seven mentioned two and the eight remaining ones mentioned only one. Among the 53 answers, the platforms Airbnb (28,3\%), Booking.com (20,8\%) and AlugueTemporada $(18,9 \%)$ were more frequently remembered by the respondents. Other platforms were also mentioned, such as: TripAdvisor (9,4\%), Decolar.com (7,5\%), HostelWorld (5,7\%), Expedia (1,9\%), FlipKey (1,9\%), HomeAway (1,9\%), Trivago (1,9\%) and Villas.com $(1,9 \%)$.

Aiming at evaluating the perception of the respondents toward collaborative consumption, sharing economy and online short-term rental platforms, the respondents were invited to evaluate nine statements. For such purpose, the five-point Likert scale was used: 1,2,3,4 and 5 correspond respectively to the options "completely disagree", "disagree", "neutral", "agree" and "completely agree". The statements were identified by letters (from A to I) to facilitate data interpretation.

A - Governors must support the progress of this type of platforms.

B - Platforms may contribute to mitigating the effects of the economic crisis and global warming.

$\mathrm{C}$ - Businesses must adapt to the changes in the market and think of new ways to generate income. 
D - Consumers can refuse the products and services from traditional businesses now.

$\mathrm{E}$ - The economic benefits are the main motivational factor to participate in activities to share goods and services.

F - Platforms represent a threat to the already established companies.

$\mathrm{G}$ - Consumers prefer to pay to have access to products and goods temporarily (without the need to buy them).

$\mathrm{H}$ - There is competition between the platforms and traditional businesses.

I - Platforms benefit the consumers who look for more convenience and better price.

Table 2 presents the frequency distribution of the answers regarding the nine statements (from A to I), by illustrating the percentage related to the five values on the Likert scale previously presented. It is verified through this table that a higher number of managers completely agreed with statement C (37,8\%); and (67,6\%) agreed with statement E. It was also observed that $43,2 \%$ of the managers of lodging businesses were neutral to statement $\mathrm{A}$. The highest disagreement was verified in relation to statement $\mathrm{D}(40,5 \%)$ and $21,6 \%$ of the managers completely disagree with statement B.

Table 2 - Frequency distribution of the statements on sharing economy, collaborative consumption and online shortterm rental platforms.

\begin{tabular}{|c|c|c|c|c|c|}
\hline \multirow{2}{*}{ STATEMENTS } & \multicolumn{5}{|c|}{ DEGREE OF AGREEMENT } \\
\hline & 5 - CA & $4-A$ & $3-\mathbf{N}$ & $2-D$ & 1 - CD \\
\hline $\begin{array}{l}\text { A - Governors must support the } \\
\text { progress of this type of platforms. }\end{array}$ & $8,1 \%$ & $16,2 \%$ & $43,2 \%$ & $18,9 \%$ & $13,5 \%$ \\
\hline $\begin{array}{l}\text { B - Platforms may contribute to } \\
\text { mitigating the effects of the } \\
\text { economic crisis and global } \\
\text { warming. }\end{array}$ & $10,8 \%$ & $21,6 \%$ & $40,5 \%$ & $5,4 \%$ & $21,6 \%$ \\
\hline $\begin{array}{l}\text { C - Businesses must adapt to the } \\
\text { changes in the market and think of } \\
\text { new ways to generate income. }\end{array}$ & $37,8 \%$ & $45,9 \%$ & $10,8 \%$ & $2,7 \%$ & $2,7 \%$ \\
\hline $\begin{array}{l}D \text { - Consumers can refuse the } \\
\text { products and services from } \\
\text { traditional businesses now. }\end{array}$ & $5,4 \%$ & $13,5 \%$ & $24,3 \%$ & $40,5 \%$ & $16,2 \%$ \\
\hline $\begin{array}{l}\text { E - The economic benefits are the } \\
\text { main motivational factor to } \\
\text { participate in activities to share } \\
\text { goods and services. }\end{array}$ & $5,4 \%$ & $67,6 \%$ & $21,6 \%$ & $5,4 \%$ & $0,0 \%$ \\
\hline $\begin{array}{l}\text { F - Platforms represent a threat to } \\
\text { the already established companies. }\end{array}$ & $8,1 \%$ & $18,9 \%$ & $35,1 \%$ & $32,4 \%$ & $5,4 \%$ \\
\hline $\begin{array}{l}\mathrm{G} \text { - Consumers prefer to pay to } \\
\text { have access to products and goods } \\
\text { temporarily (without the need to } \\
\text { buy them). }\end{array}$ & $13,5 \%$ & $37,8 \%$ & $37,8 \%$ & $10,8 \%$ & $0,0 \%$ \\
\hline $\begin{array}{l}\mathrm{H} \text { - There is competition between } \\
\text { the platforms and traditional } \\
\text { businesses. }\end{array}$ & $24,3 \%$ & $35,1 \%$ & $27,0 \%$ & $10,8 \%$ & $2,7 \%$ \\
\hline $\begin{array}{l}\text { I - Platforms benefit the consumers } \\
\text { who look for more convenience and } \\
\text { better price. }\end{array}$ & $21,6 \%$ & $40,5 \%$ & $27,0 \%$ & $8,1 \%$ & $2,7 \%$ \\
\hline
\end{tabular}


The following scenario is possible to be inferred from the formation of this table: there is agreement with five statements (C, E, G, H e I), which allows to CALCULATE a mode equal to 4; there is neutrality related to four statements $(\mathrm{A}, \mathrm{B}, \mathrm{F}$ e $\mathrm{G})$, which allows the calculation of a mode equal to three; lastly, there is disagreement with statement $\mathrm{D}$, which resulted a mode equal to 2 . It is important to emphasize that statement $G$ "Consumers prefer to pay to have access to products and goods temporarily (without the need to buy them)." is bimodal, once the same representativities appeared for modes 3 and 4 .

The results related to each one of the cities studied - Angra dos Reis, Armação dos Búzios, Cabo Frio, Paraty and Rio de Janeiro - are presented as follows.

Table 3 - Frequency distribution of statements - Angra dos Reis

\begin{tabular}{|l|c|c|c|c|c|}
\hline \multirow{2}{*}{ STATEMENTS } & \multicolumn{5}{|c|}{ DEGREE OF AGREEMENT (\%) } \\
\cline { 2 - 6 } & $\mathbf{5}$ - CA & $\mathbf{4}-\mathbf{A}$ & $\mathbf{3}-\mathbf{N}$ & $\mathbf{2}-\mathbf{D}$ & $\mathbf{1}$ - CD \\
\hline A - Governors must support the progress of this type of platforms. & 0 & $\mathbf{3 3 , 3}$ & $\mathbf{3 3 , 3}$ & $\mathbf{3 3 , 3}$ & 0 \\
\hline $\begin{array}{l}\text { B - Platforms may contribute to mitigating the effects of the } \\
\text { economic crisis and global warming. }\end{array}$ & 0 & 33,3 & $\mathbf{6 6 , 7}$ & 0 & 0 \\
\hline $\begin{array}{l}\text { C - Businesses must adapt to the changes in the market and think } \\
\text { of new ways to generate income. }\end{array}$ & $\mathbf{6 6 , 7}$ & 33,3 & 0 & 0 & 0 \\
\hline $\begin{array}{l}\text { D - Consumers can refuse the products and services from } \\
\text { traditional businesses now. }\end{array}$ & 0 & 0 & $\mathbf{1 0 0}$ & 0 & 0 \\
\hline $\begin{array}{l}\text { E - The economic benefits are the main motivational factor to } \\
\text { participate in activities to share goods and services. }\end{array}$ & 0 & $\mathbf{6 6 , 7}$ & 0 & 33,3 & 0 \\
\hline $\begin{array}{l}\text { F - Platforms represent a threat to the already established } \\
\text { companies. }\end{array}$ & 0 & 0 & $\mathbf{1 0 0}$ & 0 & 0 \\
\hline $\begin{array}{l}\text { G - Consumers prefer to pay to have access to products and goods } \\
\text { temporarily (without the need to buy them). }\end{array}$ & $\mathbf{3 3 , 3}$ & $\mathbf{3 3 , 3}$ & $\mathbf{3 3 , 3}$ & 0 & 0 \\
\hline $\begin{array}{l}\text { H - There is competition between the platforms and traditional } \\
\text { businesses. }\end{array}$ & 0 & 33,3 & $\mathbf{6 6 , 7}$ & 0 & 0 \\
\hline $\begin{array}{l}\text { I - Platforms benefit the consumers who look for more } \\
\text { convenience and better price. }\end{array}$ & 0 & 33,3 & $\mathbf{6 6 , 7}$ & 0 & 0 \\
\hline
\end{tabular}

Source: Own elaboration (2016)

From the results pointed out in table 3, it is verified that for the city of Angra dos Reis none of the respondents completely disagreed with the statements. By contrast, 66,7\% completely agreed (mode $=5$ ) with statement $\mathrm{C}$. It was also observed that $100 \%$ of the managers in Angra dos Reis were neutral (mode $=3$ ) to statements $\mathrm{D}$ and $\mathrm{F}$. A number equivalent to $66,7 \%$ of the respondents agreed (mode $=4)$ with statement $\mathrm{E}$, while $33,3 \%($ mode $=2)$ disagreed with statements $\mathrm{A}$ and $\mathrm{E}$.

The evaluation from the managers from Armação dos Búzios was the basis for elaborating table 4. It is possible to observe that $100 \%$ of the respondents from that city completely agreed (mode $=5$ ) with statement $\mathrm{E}$, and agreed (mode $=4$ ) with statement $\mathrm{H}$. About statement F, 66,7\% of the managers disagreed (mode $=2$ ). And $66,7 \%$ completely disagreed (mode $=1$ ) with statements $\mathrm{A}$ and B.

Table 4 - Frequency distribution of statements - Armação de Búzios

\begin{tabular}{|l|c|c|c|c|c|}
\hline \multirow{2}{*}{ STATEMENTS } & \multicolumn{5}{|c|}{ DEGREE OF AGREEMENT (\%) } \\
\cline { 2 - 6 } & $\mathbf{5 - C A}$ & $\mathbf{4}-\mathbf{A}$ & $\mathbf{3}-\mathbf{N}$ & $\mathbf{2}-\mathbf{D}$ & $\mathbf{1}$ - CD \\
\hline A - Governors must support the progress of this type of platforms. & 33,3 & 0 & 0 & 0 & $\mathbf{6 6 , 7}$ \\
\hline $\begin{array}{l}\text { B - Platforms may contribute to mitigating the effects of the } \\
\text { economic crisis and global warming. }\end{array}$ & 33,3 & 0 & 0 & 0 & $\mathbf{6 6 , 7}$ \\
\hline $\begin{array}{l}\text { C - Businesses must adapt to the changes in the market and think } \\
\text { of new ways to generate income. }\end{array}$ & $\mathbf{3 3 , 3}$ & $\mathbf{3 3 , 3}$ & 0 & $\mathbf{3 3 , 3}$ & 0 \\
\hline D - Consumers can refuse the products and services from & $\mathbf{3 3 , 3}$ & $\mathbf{3 3 , 3}$ & 0 & $\mathbf{3 3 , 3}$ & 0 \\
\hline
\end{tabular}




\begin{tabular}{|c|c|c|c|c|c|}
\hline traditional businesses now. & & & & & \\
\hline $\begin{array}{l}\text { E - The economic benefits are the main motivational factor to } \\
\text { participate in activities to share goods and services. }\end{array}$ & 0 & 100 & 0 & 0 & 0 \\
\hline $\begin{array}{l}\text { F - Platforms represent a threat to the already established } \\
\text { companies. }\end{array}$ & 33,3 & 0 & 0 & 66,7 & 0 \\
\hline $\begin{array}{l}\text { G - Consumers prefer to pay to have access to products and goods } \\
\text { temporarily (without the need to buy them). }\end{array}$ & 0 & 33,3 & 33,3 & 33,3 & 0 \\
\hline $\begin{array}{l}\mathrm{H} \text { - There is competition between the platforms and traditional } \\
\text { businesses. }\end{array}$ & 100 & 0 & 0 & 0 & 0 \\
\hline $\begin{array}{l}\text { I - Platforms benefit the consumers who look for more } \\
\text { convenience and better price. }\end{array}$ & 33,3 & 33,3 & 0 & 33,3 & 0 \\
\hline
\end{tabular}

Source: Own elaboration (2016)

Regarding the city of Cabo Frio, due to the reduced number of respondents and apparent divergences toward the evaluation of the statements, those statements presented biomodal nature, according to table 5. It was verified disagreement (mode $=2$ ) from $50 \%$ of the managers with statements A, B and D. It was possible to realize that $50 \%$ of the managers were neutral (mode $=3$ ) to all statements, except to statement I. Half of the respondents agreed (mode $=4$ ) with statements $\mathrm{E}, \mathrm{F}, \mathrm{G}, \mathrm{H}$ e I, while $50 \%$ completely agreed (mode $=5$ ) with statements $\mathrm{C}$ and $\mathrm{I}$. The mode for each statement is presented in Table 5 below.

Table 5 - Frequency distribution of statements - Cabo Frio

\begin{tabular}{|l|c|c|c|c|c|}
\hline \multirow{2}{*}{ STATEMENTS } & \multicolumn{4}{|c|}{ DEGREE OF AGREEMENT (\%) } \\
\cline { 2 - 6 } & $\mathbf{5 - C A}$ & $\mathbf{4 - A}$ & $\mathbf{3 - N}$ & $\mathbf{2}$ - D & $\mathbf{1}$ - CD \\
\hline A - Governors must support the progress of this type of platforms. & 0 & 0 & $\mathbf{5 0}$ & $\mathbf{5 0}$ & 0 \\
\hline $\begin{array}{l}\text { B - Platforms may contribute to mitigating the effects of the } \\
\text { economic crisis and global warming. }\end{array}$ & 0 & 0 & $\mathbf{5 0}$ & $\mathbf{5 0}$ & 0 \\
\hline $\begin{array}{l}\text { C - Businesses must adapt to the changes in the market and think } \\
\text { of new ways to generate income. }\end{array}$ & $\mathbf{5 0}$ & 0 & $\mathbf{5 0}$ & 0 & 0 \\
\hline $\begin{array}{l}\text { D - Consumers can refuse the products and services from } \\
\text { traditional businesses now. }\end{array}$ & 0 & 0 & $\mathbf{5 0}$ & $\mathbf{5 0}$ & 0 \\
\hline $\begin{array}{l}\text { E - The economic benefits are the main motivational factor to } \\
\text { participate in activities to share goods and services. }\end{array}$ & 0 & $\mathbf{5 0}$ & $\mathbf{5 0}$ & 0 & 0 \\
\hline $\begin{array}{l}\text { F - Platforms represent a threat to the already established } \\
\text { companies. }\end{array}$ & 0 & $\mathbf{5 0}$ & $\mathbf{5 0}$ & 0 & 0 \\
\hline $\begin{array}{l}\text { G - Consumers prefer to pay to have access to products and goods } \\
\text { temporarily (without the need to buy them). }\end{array}$ & 0 & $\mathbf{5 0}$ & $\mathbf{5 0}$ & 0 & 0 \\
\hline $\begin{array}{l}\text { H - There is competition between the platforms and traditional } \\
\text { businesses. }\end{array}$ & 0 & $\mathbf{5 0}$ & $\mathbf{5 0}$ & 0 & 0 \\
\hline $\begin{array}{l}\text { I - Platforms benefit the consumers who look for more } \\
\text { convenience and better price. }\end{array}$ & $\mathbf{5 0}$ & $\mathbf{5 0}$ & 0 & 0 & 0 \\
\hline
\end{tabular}

Source: Own elaboration (2016)

About the results of the evaluation from the managers from the city of Paraty, presented in table 6 , it is possible to realize that $28,6 \%$ of them completely agreed (mode $=5$ ) with statement $\mathrm{H}$. In relation to statement $C, 71,4 \%$ agreed that the businesses need to adapt to changes in the market. On the other hand, $50 \%$ of the respondents were neutral (mode $=3$ ) to statement $\mathrm{G}$ and $64,3 \%$ disagreed (mode $=2$ ) with statement $\mathrm{D}$.

Table 6 - Frequency distribution of statements - Paraty

\begin{tabular}{|l|c|c|c|c|c|}
\hline \multirow{2}{*}{ STATEMENTS } & \multicolumn{4}{|c|}{ DEGREE OF AGREEMENT (\%) } \\
\cline { 2 - 5 } & $\mathbf{5}-\mathbf{C A}$ & $\mathbf{4}-\mathbf{A}$ & $\mathbf{3}$ - N & $\mathbf{2}$ - D & $\mathbf{1}$ - CD \\
\hline A - Governors must support the progress of this type of platforms. & 7,1 & 21,4 & $\mathbf{4 2 , 9}$ & 14,3 & 14,3 \\
\hline B - Platforms may contribute to mitigating the effects of the & 7,1 & 28,6 & $\mathbf{3 5 , 7}$ & 7,1 & 21,4 \\
\hline
\end{tabular}




\begin{tabular}{|c|c|c|c|c|c|}
\hline economic crisis and global warming. & & & & & \\
\hline $\begin{array}{l}\text { C - Businesses must adapt to the changes in the market and think } \\
\text { of new ways to generate income. }\end{array}$ & 14,3 & 71,4 & 7,1 & 0 & 7,1 \\
\hline $\begin{array}{l}\mathrm{D} \text { - Consumers can refuse the products and services from } \\
\text { traditional businesses now. }\end{array}$ & 0 & 0 & 14,3 & 64,3 & 21,4 \\
\hline $\begin{array}{l}\mathrm{E}-\text { The economic benefits are the main motivational factor to } \\
\text { participate in activities to share goods and services. }\end{array}$ & 7,1 & 64,3 & 28,6 & 0 & 0 \\
\hline $\begin{array}{l}\text { F - Platforms represent a threat to the already established } \\
\text { companies. }\end{array}$ & 14,3 & 7,1 & 28,6 & 50 & 0 \\
\hline $\begin{array}{l}\text { G - Consumers prefer to pay to have access to products and goods } \\
\text { temporarily (without the need to buy them). }\end{array}$ & 7,1 & 28,6 & $\mathbf{5 0 , 0}$ & 14,3 & 0 \\
\hline $\begin{array}{l}\mathrm{H} \text { - There is competition between the platforms and traditional } \\
\text { businesses. }\end{array}$ & 28,6 & 35,7 & 21,4 & 14,3 & 0 \\
\hline $\begin{array}{l}\text { I - Platforms benefit the consumers who look for more } \\
\text { convenience and better price. }\end{array}$ & 14,3 & 57,1 & 21,4 & 7,1 & 0 \\
\hline
\end{tabular}

Source: Own elaboration (2016)

About the city of Rio de Janeiro, table 7 was created, in which it is possible to verify that the majority of the managers $(53,3 \%)$ completely agreed (mode $=5$ ) with statement $\mathrm{C}$. Regarding the fact that the economic benefits are the main motivational factor to participate in sharing activities, $66,7 \%$ of the respondents agreed (mode $=4$ ). Regarding the government's support toward the progress of platforms, $53,3 \%$ of the managers were neutral (mode $=3$ ). $26,7 \%$ disagreed $($ mode $=2$ ) with statement D, while 20,0\% completely disagreed (mode $=1$ ) with statements B and D.

Table 7 - Frequency distribution of statements - Rio de Janeiro

\begin{tabular}{|l|c|c|c|c|c|}
\hline \multirow{2}{*}{ STATEMENTS } & \multicolumn{5}{|c|}{ DEGREE OF AGREEMENT (\%) } \\
\cline { 2 - 5 } & $\mathbf{5 - C A}$ & $\mathbf{4 - A}$ & $\mathbf{3}$ - N & $\mathbf{2}$ - D & 1 - CD \\
\hline A - Governors must support the progress of this type of platforms. & 6,7 & 13,3 & $\mathbf{5 3 , 3}$ & 20 & 6,7 \\
\hline $\begin{array}{l}\text { B - Platforms may contribute to mitigating the effects of the } \\
\text { economic crisis and global warming. }\end{array}$ & 13,3 & 20 & $\mathbf{4 6 , 7}$ & 0 & 20 \\
\hline $\begin{array}{l}\text { C - Businesses must adapt to the changes in the market and think } \\
\text { of new ways to generate income. }\end{array}$ & $\mathbf{5 3 , 3}$ & 33,3 & 13,3 & 0 & 0 \\
\hline $\begin{array}{l}\text { D - Consumers can refuse the products and services from } \\
\text { traditional businesses now. }\end{array}$ & 6,7 & $\mathbf{2 6 , 7}$ & 20 & $\mathbf{2 6 , 7}$ & 20 \\
\hline $\begin{array}{l}\text { E - The economic benefits are the main motivational factor to } \\
\text { participate in activities to share goods and services. }\end{array}$ & 6,7 & $\mathbf{6 6 , 7}$ & 20 & 0 & 6,7 \\
\hline $\begin{array}{l}\text { F - Platforms represent a threat to the already established } \\
\text { companies. }\end{array}$ & 0 & $\mathbf{3 3 , 3}$ & $\mathbf{3 3 , 3}$ & 20 & 13,3 \\
\hline $\begin{array}{l}\text { G - Consumers prefer to pay to have access to products and goods } \\
\text { temporarily (without the need to buy them). }\end{array}$ & 20 & $\mathbf{4 6 , 7}$ & 26,7 & 0 & 6,7 \\
\hline $\begin{array}{l}\text { H - There is competition between the platforms and traditional } \\
\text { businesses. }\end{array}$ & 13,3 & $\mathbf{4 0}$ & 26,7 & 13,3 & 6,7 \\
\hline $\begin{array}{l}\text { I - Platforms benefit the consumers who look for more } \\
\text { convenience and better price. }\end{array}$ & 26,7 & 26,7 & $\mathbf{3 3 , 3}$ & 6,7 & 6,7 \\
\hline
\end{tabular}

Source: Own elaboration (2016)

From the analysis of the identified modes for each statement in all cities, it is possible to realize that five out of nine statements brought up in the literature review stand out: C, E, G, H e I. It was verified that the managers, in their majority, agreed that the businesses must adapt to the changes in the market and think of new ways to generate income; that the economic benefits are the main motivational factor in sharing activities; that consumers prefer to pay to have access to products and goods temporarily (without the need to buy them); that there is competition between the platforms and traditional businesses; and that the platforms benefit the consumers who look for more convenience and better price. 
It can be inferred from such result that the majority of the answers from the managers is aligned with the facts presented in the literature, once the statements contained in the questionnaire were originated from it. At the same time, it is also possible to suggest that the understanding of the respondents regarding sharing economy, collaborative consumption and online short-term rental platforms is partial, once they only agreed with part of these statements.

\section{CONCLUSIONS}

The recent phenomenon of sharing economy brought significant market changes, especially regarding the behavior of the consumers. With the emerging of new technologies, the sharing of idle individual goods became easier and it was possible to observe the appearance of several digital platforms created to promote collaborative consumption.

Different sectors were impacted by this consumption pattern, characterized by the prioritization of the sharing of goods to the detriment of property. In the tourism sector, it was verified that new business models appeared in this context, such as the online short-term rental platforms that connect hosts and prospective guests, and may represent a threat to traditional lodging businesses.

Keeping in mind that such platforms may not only present competitive advantage related to the already established businesses, but also modify the logistic of competition in the sector, the present work aimed at investigating how the collaborative consumption of accommodation is realized by the managers of lodging businesses from five cities of the State of Rio de Janeiro. The results obtained from the application of a research questionnaire allowed to map the understanding of the managers toward the phenomenon of sharing economy, collaborative consumption and online short-term rental platforms.

Having as basis the modified modes, it was possible to observe that five out of the nine statements mentioned in the questionnaire were validated by the managers who answered it. They were:

- $\quad$ Platforms benefit the consumers who look for more convenience and better price.

- There is competition between the platforms and traditional businesses.

- Consumers can refuse the products and services from traditional businesses now.

- The economic benefits are the main motivational factor to participate in activities to share goods and services. generate income.

It is worthy emphasizing that the need of the companies to adapt to the changes was pointed out as the statement that had the highest degree of agreement from the managers, followed by the statement that mentions the economic benefits as the main motivational factor to participate in activities to share goods and services.

It was also verified that three of the statements the managers agreed with refer to economic/financial issues that, according to their evaluation, represent a relevant aspect toward online platforms and the context of sharing economy and collaborative consumption.

The statement that addresses the competition between the platforms and traditional businesses is also worth highlighting, especially because the sample of this work was composed predominantly by micro and small-size enterprises. The evaluation from the managers, when 
revealing that the online platforms are realized as a threat to the competitiveness of their businesses, may indicate that the segmentation or differentiation strategies are not quite defined or are inexistent in such enterprises. Consequently, they are not able to generate a higher value than the one offered by the owners of the properties listed on the platforms, and thus, start competing with those entrants.

The other statements were evaluated in an indifferent way and did not present any degree of agreement from the managers. Keeping in mind that the statements contained in the questionnaire originated from the literature review on the theme, such result may reveal two distinct facts.

The first one refers to the partial understanding of sharing economy, collaborative consumption and online short-term rental platforms from the respondents. On the other hand, this result may also indicate that only part of the facts that are reported in the literature was realized by the managers of lodging businesses.

It is important to remember that the present study has limitations that do not allow the complete mapping of the effects felt in the lodging segment of the State of Rio de Janeiro and, consequently, the perception of the involved managers. Nonetheless, it was aimed at contributing toward a better understanding of the recent phenomenon of sharing economy and collaborative consumption.

It is recommended that other studies be performed in the future, not only on the approached themes in this article but also on related thematics, such as the profile of the consumers who opt for hiring lodging services via online platforms to the detriment of traditional lodging businesses, the economic impacts experienced by the tourist destinations where the short-term rental platforms form a bigger market in relation to traditional businesses, the benefits toward sustainability promoted by the sharing of idle goods, among others. Therefore, there will be more clarity toward the changes felt in the tourism sector as a whole, and the possibility the businesses may find options for dealing with the challenges of modern times will be higher.

\section{REFERENCES}

BARDHI, F.; ECKHARDT, G. M. Access-based consumption: the case of car sharing. Journal of Consumer Research, v. 39, dez. 2012, p. 881-898.

BELK, R. You are what you can access: sharing and collaborative consumption online. Journal of Business Research, v. 67, n. 8 , p. $1595-1600,2014$.

BOESLER, Matthew. The rise of the renting and sharing economy could have catastrophic ripple effects. Business Insider, 12 ago. 2013. Retrieved from: <http://www.businessinsider.com/rise-of-the-renting-and-sharing-economy2013-8?op=1>.

BOTSMAN, R. Defining the sharing economy: what is collaborative consumption - and what isn't? Fast Company, 2015. Retrieved from: <http://www.fastcoexist.com/3046119/defining-the-sharing-economy-what-is-collaborativeconsumption-and-what-isnt>.

CEROY, Frederico Meinberg. Uber e Netflix são a ponta do iceberg da economia compartilhada. IDGNow, 2015. Retrieved from: <http://idgnow.com.br/internet/2015/07/06/artigo-uber-e-netflix-sao-a-ponta-do-iceberg-da-economiacompartilhada>.

CHOI, H. R.; CHO, M. J.; LEE, K.; HONG, S. G.; WOO, C. R.. The business model for the sharing economy between SMEs. WSEAS Transactions on Business and Economics, 2014. Retrieved from: <http://www.wseas.org/multimedia/journals/economics/2014/a125707-287.pdf>.

CHRISTENSEN, Clayton M. O dilema da inovação, vol. 261. São Paulo: Makron Books, 2001. 
COMPARTILHAR serviços e produtos vira tendência entre consumidores. Retrieved from: <http://g1.globo.com/jornal-nacional/noticia/2015/07/compartilhar-servicos-e-produtos-vira-tendencia-entreconsumidores.html>.

CUSUMANO, Michael A. Technology strategy and management: how traditional firms must compete in the sharing economy. Communications of the ACM, vol. 58, n. 1, jan. 2015.

ECKHARDT, G. M.; BARDHI, F. The sharing economy isn't about sharing at all. Harvard Business Review, jan. 2015. Retrieved from: <https://hbr.org/2015/01/the-sharing-economy-isnt-about-sharing-at-all>. Acesso em: fev. 2016.

GOEL, S. Capitalism Versus the Sharing Economy. UC Berkeley: UC Berkeley Library, 2014. Retrieved from: <http://www.escholarship.org/uc/item/8xd4m19w>.

GRAY, David E. Pesquisa no mundo real. Porto Alegre: Penso, 2012.

HAMARI, J.; SJÖKLINT, M.; UKKONEN, A. The sharing economy: why people participate in collaborative consumption. Journal of the Association for Information Science and Technology, p. 1-19, 2015. Retrieved from: <http://www.ssrn.com/abstract=2271971>.

HENTEN, A. H.; WINDEKILDE, I. M. Transaction costs and the sharing economy. Info, v. 18, n. 1, p. 1-15, 2016.

MATZLER, K.; VEIDER, V.; KATHAN, W. Adapting to the sharing economy. MIT Sloan Management Review, v. 56, n. 2, p. 71-77, 2015.

MINISTÉRIO DO TURISMO. Categorização dos municípios das regiões turísticas do Mapa do Turismo Brasileiro. Retrieved from: <http://www.turismo.gov.br/sem-categoria/5854-categoriza\%C3\%A7\%C3\%A3o-dosmunic\%C3\%ADpios-das-regi\%C3\%B5es-tur\%C3\%ADsticas-do-mapa-do-turismo-brasileiro.html>.

QUINSON, E. Collaborative consumption through new technologies. Centria University of Applied Sciences, 2015.

TEUBNER, T. Thoughts on the sharing economy. of the International Conference on e-Commerce. p. 322-326, 2014. Retrieved from: <http://www.scopus.com/inward/record.url?eid=2-s2.0-84929379218\&partnerID=tZOtx3y1>.

ZERVAS, Georgios; PROSERPIO, Davide; BYERS, John. The rise of the sharing economy: estimating the impact of Airbnb on the hotel industry. (May 7, 2015). Boston University School of Management Research. Retrieved from: $<$ http://ssrn.com/abstract=2366898>. 